\title{
TREATMENT OF FRACTURE SHAFT FEMUR IN PAEDIATRIC AGE GROUP WITH TITANIUM ELASTIC NAIL
}

\author{
Kishan Gopal Nama1 ${ }^{1}$ Ram Khiladi Meena², Bal Mukund ${ }^{3}$, Bharat ${ }^{4}$, Dinesh Meena ${ }^{5}$
}

${ }^{1}$ Assistant Professor, Department of Orthopaedics, M.B.S. Hospital and Government Medical College, Kota. ${ }^{2}$ Assistant Professor, Department of Orthopaedics, M.B.S. Hospital and Government Medical College, Kota. ${ }^{3} 3^{\text {rd }}$ Year Resident, Department of Orthopaedics, M.B.S. Hospital and Government Medical College, Kota. ${ }^{4} 2^{\text {nd }}$ Year Resident, Department of Orthopaedics, M.B.S. Hospital and Government Medical College, Kota. ${ }_{5}^{5}$ Associate Professor, Department of Orthopaedics, M.B.S. Hospital and Government Medical College, Kota.

\section{ABSTRACT}

\section{BACKGROUND}

In this era of speed, management of fracture of shaft femur in paediatric age group have changed from conservative to operative. This reduced the chance of malunion, rotation and angulation along with allow early mobilisation to minimise the morbidity and complications for the child. In this study, we intend to evaluate the functional and radiological outcome of diaphyseal fracture of shaft of femur in children treated with titanium elastic intramedullary nail.

\section{MATERIALS AND METHODS}

In this study, 30 patients of 4 - 14 years' age group with femoral fractures were treated with TENS nail.

\section{RESULTS}

In this study, outcome was assessed by using Flynn's criteria of titanium flexible nail outcome score. Average operative time was 35 minutes. Partial weight bearing started was at 5 weeks and full weight bearing was started at 8 weeks. Most cases $63.4 \%$ were having excellent results, $33.3 \%$ were having satisfactory results and $3.3 \%$ were having poor results. One case was having superficial infection, which was controlled by antibiotic.

\section{CONCLUSION}

TENS nail is having excellent result in fracture shaft femur in paediatric age group with less side effects. So it is surgeon's and patient's friendly implant.

\section{KEYWORDS}

Fracture Shaft Femur, Titanium Elastic Nail.

HOW TO CITE THIS ARTICLE: Nama KG, Meena RK, Mukund B, et al. Treatment of fracture shaft femur in paediatric age group with titanium elastic nail. J. Evolution Med. Dent. Sci. 2017;6(65):4729-4732, DOI: 10.14260/Jemds/2017/1024

\section{BACKGROUND}

Femoral shaft fractures are common injuries in paediatric age group and represent nearly $1.6 \%-2 \%$ of all bony injuries in children. ${ }^{1,2,3}$ In the last decade, the management of paediatric femoral fractures has evolved from non-operative to operative approach. ${ }^{4,5}$ Traditional management of paediatric femoral shaft fractures has been by immobilisation in spica cast. Indications for surgical management were few including open fracture with extensive soft tissue trauma, children with associated injuries like head injury, abdominal injury or polytrauma. In non-operative treatment, it has been noticed that problems such as angulation, malrotation and limb length discrepancy cannot be effectively controlled. The goals should be to stabilise the fracture, to control length and alignment, to promote bone healing and to minimise the morbidity and complications for the child.

Among the various operative treatments such as plating, external fixator, rigid intramedullary nailing and elastic

Financial or Other, Competing Interest: None.

Submission 19-07-2017, Peer Review 01-08-2017,

Acceptance 07-08-2017, Published 14-08-2017.

Corresponding Author:

Dr. Kishan Gopal Nama,

\#B-17, Civil Line,

Opposite M.B.S. Hospital, Kota.

E-mail: drkgnama1808@gmail.com

DOI: $10.14260 /$ jemds/2017/1024 stable intramedullary nailing has become gold standard now. Ender ${ }^{6}$ developed this further with his nails, which were the first to feature adaptations to both ends of the nail in order to improve both control of insertion and quality of fixation. In the early 1980s surgeons in Nancy, France, developed an elastic stable intramedullary nail based on a theoretical concept by Firica. ${ }^{7}$ Previous experience had suggested that elasticity and stability were not easily combined in one construct. However, working from the concept of three-point fixation used with a single Rush nail, these surgeons were able to improve stability significantly by using two pre-tensioned nails inserted from opposite sides of the bone. ${ }^{8}$

In this study, we intend to evaluate the functional and radiological outcome of diaphyseal fracture of shaft of femur treated with elastic intramedullary nail.

\section{MATERIALS AND METHODS}

In this prospective study, thirty patients with diaphyseal fracture femur were treated with titanium elastic nail in M.B.S. Hospital and Medical College, Kota from July 2014 to April 2017.

We included children between 4 - 11 years with fracture shaft femur at least $3 \mathrm{~cm}$ distal to lesser trochanter and $4 \mathrm{~cm}$ proximal to physis.

This study is not limited to children below four years and above 14 years, comminuted, high sub-trochanteric and pathological fractures and bilateral fracture. 


\section{Objective}

In this study, we intend to evaluate the functional and radiological outcome of diaphyseal fracture of shaft of femur in children treated with Titanium elastic intramedullary nail.

\section{Operative Technique}

Patient was taken on a fracture table and traction was applied under fluoroscopic guidance to reduce the fracture. Proper size elastic nails of 2 to $3.5 \mathrm{~mm}$ diameter were taken. Nails were slightly bent in an even curve. This facilitates the nail to bounce off the opposite cortex into the canal and gives threepoint fixation. After incising the skin, soft tissue was separated with the help of artery. Using awl insertion points were made, one on lateral and another on medial side of distal femur, 1 - 2 $\mathrm{cm}$ proximal to the distal epiphyseal plate. The selected nail is introduced and gently tapped along the medulla with the tip angled away from the cortex. The nails were introduced right up to fracture site, then reduction was achieved at fracture site and one of the nail was passed across the already reduced fracture site followed by second one. The nails were guided in such a way that end of medial nail was introduced into the neck and end of lateral nail just below trochanteric apophysis in a divergent shaped manner. Two divergent elastic nails provide adequate fixations and stability in adolescent femur., ${ }^{9,10} \mathrm{We}$ slightly bend the nail before cutting.

Knee bending and quadriceps strengthening exercises were started as soon as the patient could tolerate it, usually within first $24 \mathrm{hrs}$. itself. Non-weight bearing ambulation was started within first few days, though partial weight bearing was permitted only after radiological evidence of callus formation. Full weight bearing was permitted only on radiological evidence of firm union. Minimum followup of the patient was 1 year.

\section{RESULTS}

Between March 2015 and April 2017, 30 children with 30 femoral shaft fractures were treated with Titanium Elastic nails. Ages of children ranged from 4 - 14 years (average 7.7 years). There were 21 boys and 9 girls. The M: F ratio in our study was 7: 3 . In our series, 25 patients sustained injury due to fall from height and 5 patients sustained injury due to road traffic accident.

Out of 30 fractures, 19 (63.3\%) were of the right side and $11(36.7 \%)$ were of left side. In all 19 fractures were in middle third, 4 in distal third and 7 in proximal third; 18 cases had transverse fracture, 5 were oblique and 7 were spiral in pattern. On Winquist ${ }^{11}$ grading system 16 were grade I, 8 were grade II, 4 was grade III and 2 was grade IV; 1 segmental fracture was seen. Open fractures and bilateral fractures were not included. Associated injuries were seen in 5 cases.

In this study, the minimum interval between injury and surgery was one day and maximum was seven days. In our study, minimum days of hospital stay were 3 days and maximum were 11 days. The mean hospital stay was 6 days. The average duration of surgery was 35 mins. Except one case, all cases were operated closely. Average blood loss was $40 \mathrm{~mL}$. Knee bending and quadriceps strengthening exercises were begun as soon as patient was able to do. Partial weight bearing was begun around 4 weeks depending on fracture configuration, callus formation and patient tolerance. Full weight bearing was begun in about 6 - 9 weeks' time in most of the cases. The average time to partial weight bearing was
4.3 weeks, full weight bearing was 8 weeks ( 5 to 12 weeks), full movement was achieved in 11 weeks ( 8 to 16 weeks); 24 patients out of 30 had limb length discrepancy of $10 \mathrm{~mm}$ at 24 weeks followup, while 5 patients had limb length discrepancy of $15 \mathrm{~mm}, 1$ patient had limb length discrepancy of $21 \mathrm{~mm} ; 19$ out of 30 patients had angulations of less than 5 degrees, while 10 patients had angulations between 5 to 10 degrees and 1 patient had angulations of more than 10 degrees at 24 weeks followup. In this study, out of 30 cases 21 cases had full range of movement, while 8 had range of movement of 120 degrees and 1 case had range of movement of 110 degrees at 24 weeks followup. In our study, majority of cases $63.33 \%$ had excellent and $33.3 \%$ had satisfactory and $3.33 \%$ had poor result.

\begin{tabular}{|c|c|c|}
\hline Limb Length Discrepancy & Patients Number & Percentage \\
\hline Less than $10 \mathrm{~mm}$ & 24 & 80 \\
\hline $10 \mathrm{~mm}$ to $20 \mathrm{~mm}$ & 5 & 16.7 \\
\hline More than $2 \mathrm{~cm}$ & 1 & 3.3 \\
\hline
\end{tabular}

\begin{tabular}{|c|c|c|}
\hline Angulation & Patients Number & Percentage \\
\hline 5 degrees or less & 19 & 63.3 \\
\hline 6 - 10 degrees & 10 & 33.3 \\
\hline More than 10 degrees & 1 & 3.33 \\
\hline \multicolumn{2}{|c|}{ Table 2. Angulation and Percentage } \\
\hline
\end{tabular}

\section{Followup}

The average followup was 13 months ( 8 to 24 months). By this time, all the patients had full-unrestricted activity; 24 patients out of 30 had limb length shortening of less than $10 \mathrm{~mm}$ at 24 weeks followup, while 5 patients had limb length discrepancy of $12 \mathrm{~mm}$ and one had more than $20 \mathrm{~mm} ; 19$ patients had angulations of five degrees or less, while 10 patients had angulations between 5 to 10 degrees and 1 patient had angulations of more than 10 degrees at 24 weeks followup. In this study, out of 30 cases 21 cases had full range of movement, while 7 had range of movement of 120 degrees and 2 cases had range of movement of 110 degrees at 24 weeks followup.

\begin{tabular}{|c|c|c|c|}
\hline $\begin{array}{c}\text { Results } \\
\text { (Variables } \\
\text { at 24 Weeks) }\end{array}$ & Excellent & Satisfactory & Poor \\
\hline $\begin{array}{c}\text { Limb-length } \\
\text { inequality }\end{array}$ & $<1.0 \mathrm{~cm}$ & $<2.0 \mathrm{~cm}$ & $>2.0 \mathrm{~cm}$ \\
\hline Malalignment & 5 degrees & 10 degrees & $>10$ degrees \\
\hline Pain & None & None & Present \\
\hline $\begin{array}{c}\text { Other } \\
\text { complications }\end{array}$ & None & $\begin{array}{c}\text { Minor and } \\
\text { resolved }\end{array}$ & $\begin{array}{c}\text { Major and lasting } \\
\text { morbidity }\end{array}$ \\
\hline \multicolumn{4}{|c|}{ Table 3. Flynn's Criteria. TENS } \\
Outcome Score (Flynn et al) \\
\hline
\end{tabular}

\section{Complications}

One case was having superficial infection, which was controlled by antibiotics and one case was having protrusion of nail. In those cases, the nail was removed earlier after formation of callus. In our study, no deep infection occurred.

\section{DISCUSSION}

The management of children with femoral shaft fractures in the age group of $4-14$ years is dilemma to orthopaedic 
surgeons. Conservative treatment with spica has disadvantages such as prolonged hospital stay, angular and torsional deformity and shortening. Many orthopaedician reserve surgical management for open fracture, multiple trauma, associated head injuries, burns and neuromuscular wounding. External fixation causes high rate of pin tract infections and chance of refracture after removal of fixator. ${ }^{13-}$ 15 Rigid intramedullary nailing may damage the blood supply to the femoral head resulting in AVN or causing growth arrest at the greater trochanter.

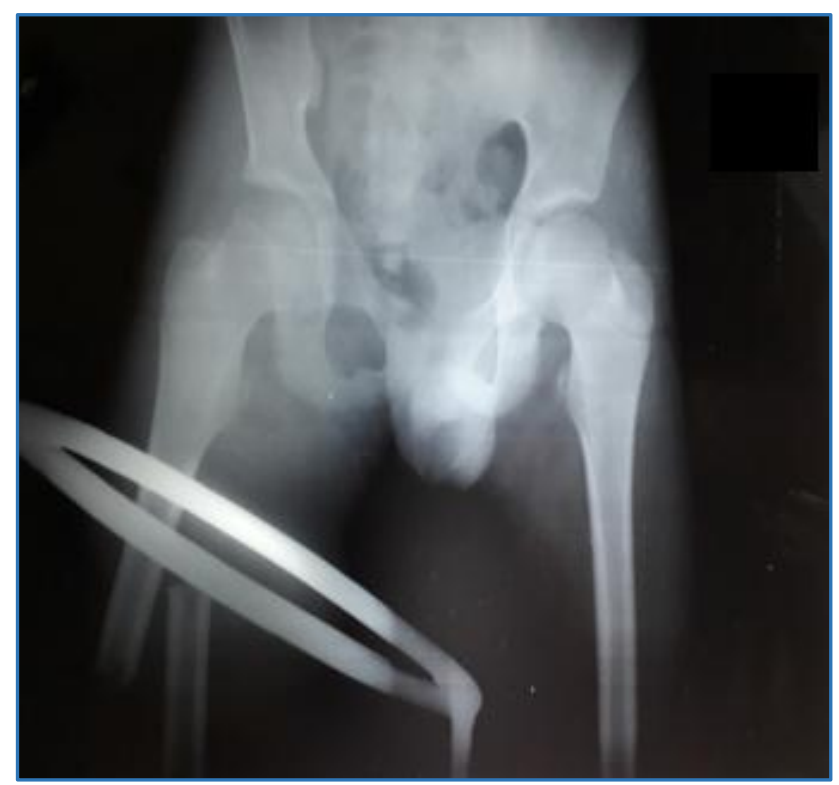

Figure 1. Preop.

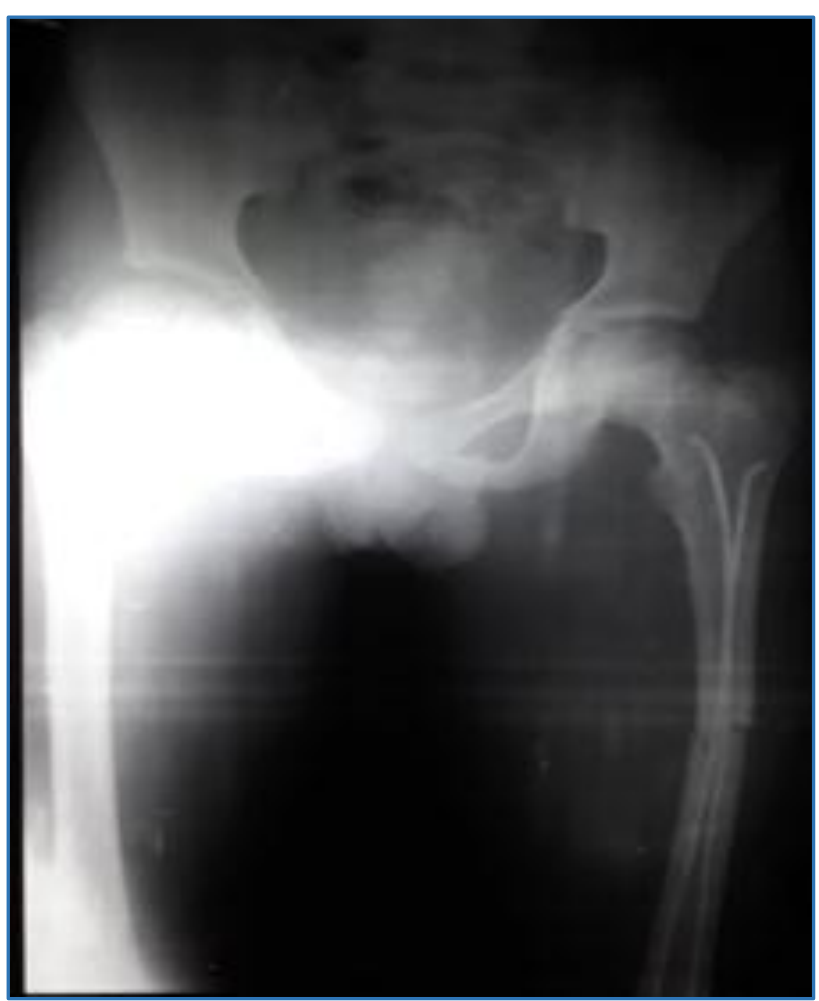

Figure 2. Postop.

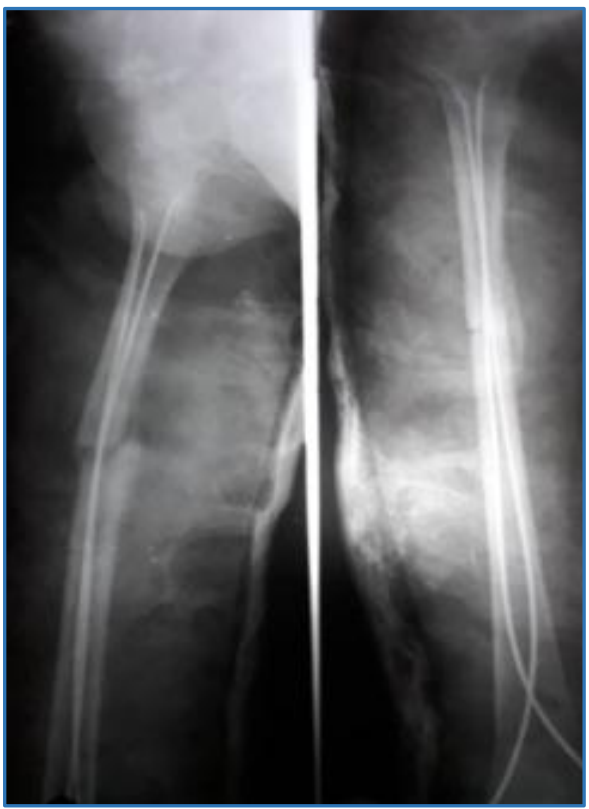

Figure 3. Four Weeks Later

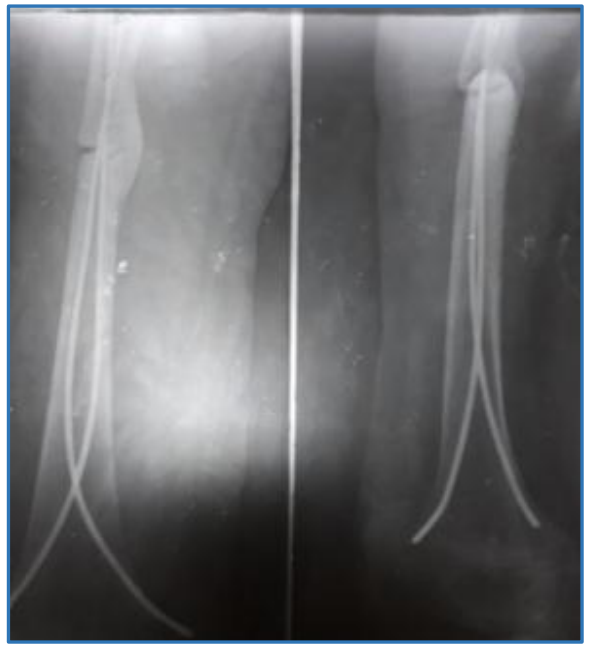

Figure 4. Eight Weeks Later

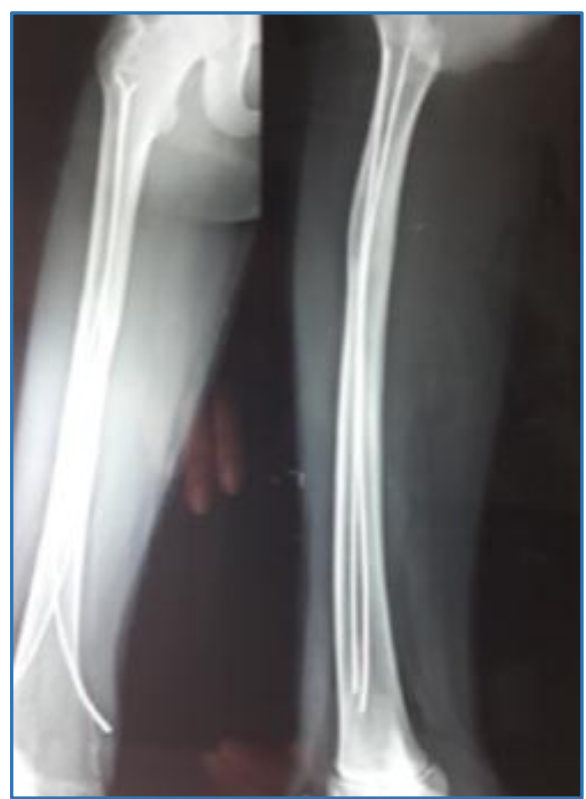

Figure 5. After Union 


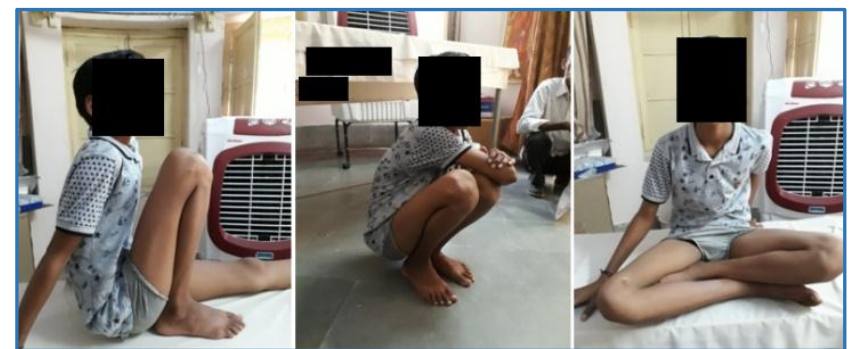

Figure 6, 7, 8. Full Range of Motion in Various Positions

In our series, average duration of hospital stay was 6 days (range 3 to 11 days), whereas in a study conducted by Houshian et al ${ }^{15}$ the mean hospital stay was 6 days and range of hospital stay was 2 to 20 days. In a study done by Dr. Shrawan Kumar Thapa et al,16 the duration of hospital stays were between 5 to 12 days. In our study, 25 (83.3\%) cases were due to fall from height and $5(16.7 \%)$ cases were due to road traffic accident. The major cause of fracture was road traffic accident in $42(75 \%)$ cases followed by fall from tree in $13(23.2 \%)$ cases in a study done by Dr. S K Thapa et al. ${ }^{16}$ In our study, 19 (63.3\%) cases were having right-sided trauma and 11 (36.7) cases were having left-sided trauma which was comparable to study done by Dr. S K Thapa et al. In our study mean blood loss was $40(+/-5 \mathrm{~mL})$; in study done by Saha P et al it was $70 \mathrm{~mL}$ with duration of 25 minutes comparable to our study of 45 minutes. The average time to partial weight bearing was 4.3 weeks, full weight bearing was 8 weeks ( 5 to 12 weeks) and full movement was achieved in 11 weeks ( 8 to 16 weeks) in our study.

The fracture heals within 8 to 10 weeks in M Bary study.

The average time to full weight bearing was 6.6 weeks ( 5 to 12 weeks), full movement was achieved in 9 weeks ( 6 to 15 weeks) in Ibrahim study.

In our study, majority of cases (63.33\%) had excellent and $33.3 \%$ had satisfactory and $3.33 \%$ had poor result which was comparable to series reported by Pulate et al. ${ }^{17}$ Results were excellent in 12 patients (60\%), successful in 7 (35\%) and poor in 1 patient (5\%). In Moroz et al ${ }^{18}$ study it was excellent in 150 (65\%), satisfactory in $57(25 \%)$ and poor in $23(10 \%)$.

\section{CONCLUSION}

Titanium elastic intramedullary nail for fracture shaft femoral in children is the gold standard, easy technique of insertion, proper stabilisation and movement of lower limb. It is ideal and cost effective with short hospital stay and minimal complications.

\section{REFERENCES}

[1] Gardner MJ, Lawrence BD, Griffith MH. Surgical treatment of paediatric femoral shaft fractures. Curr Opin Paediatr 2004;16(1):51-7.

[2] Kanellopoulos AD, Yiannakopoulos CK, Soucacos PN. Closed, locked intramedullary nailing of paediatric femoral shaft fractures through the tip of the greater trochanter. J Trauma 2006;60(1):217-23.
[3] Kandil HM. Titanium flexible intramedullary nailing of paediatric femoral shaft fractures. KEAMJ 2007;13(3):45-50.

[4] Saha P, Ghosh A, Khan HA, et al. Analysis of results of Titanium Elastic Nails (TENs) and ender nails: a comparative study. Int J Sci Stud 2015;3(4):81-5.

[5] Barry $M$, Paterson JMH. ASPECTS OF CURRENT MANAGEMENT. Flexible intramedullary nails for fractures in children. J Bone Joint Surg [Br] 2004;86B(7):947-53.

[6] Enders J, Simon-Weidner R. Die fixierung der trochanteren bruche mit rundenelastischen condylennageln. Acta Chir Austr 1970:2-40.7

[7] Mazda K, Khairouni A, Pennecot GF, et al. Closed flexible intramedullary nailing of the femoral shaft fractures in children. J Pediatr Orthop B 1997;6(3):198-202.

[8] Ligier JN, Metaizeau JP, Prevot J, et al. Elastic stable intramedullary nailing of femoral shaft fracture in children. JBJS 1988;70(1):74-7.

[9] Lee SS, Mahar AT, Newton PO. Ender nail fixation of pediatric femur fractures: a biomechanical analysis. J Pediatr Orthop 2001;21(4):442-5.

[10] Moroz LA, Launay F, Kocher MS, et al. Titanium elastic nailing of fractures of the femur in children. Predictors of complications and poor outcome JBJS $\mathrm{Br}$ 2006;88(10):1361-6.

[11] Winquist RA, Hansen ST. Comminuted fractures of the femoral shaft treated by intramedullary nailing. Orthop Clin Nort Am 1980;11(3):633-48.

[12] Flynn JM, Hresko T, Reynolds RA, et al. Titanium elastic nails for pediatric femur fractures: a multicenter study of early results with analysis of complications. J Pediatr Orthop 2001;21(1):4-8.

[13] Razak MYA, El-Karef EA, Soliman AS, et al. Result of flexible intramedullary nailing in paediatric femoral fractures. Bull Alex Fac Med 2008;44:729-35.

[14] El-Adl G, Mostafa MF, Khalil MA, et al. Titanium elastic nail fixation for paediatric femoral and tibial fractures. Acta Orthop Belg 2009;75(4):512-20.

[15] Houshian S, Gothgen CB, Pedersen NW. Femoral shaft fractures in children: elastic stable intramedullary nailing in 31 cases. Acta Orthop Scand 2004;75(3):24951.

[16] Thapa SK, Poudel KP, Marasini RP, et al. Paediatric diaphyseal femur fracture treated with intramedullary titanium elastic nail system. JCMS Nepal 2015;11(2):20-2.

[17] Pulate A, Jadhav A, Shah BN. Study of the outcome of titanium elastic nail system in diaphyseal femoral fractures in children. MOA Journal 2012;7(3):6-8.

[18] Khazzam M, Tassone C, Liu XC, et al. Use of flexible intramedullary nail fixation in treating femur fractures in children. Am J Orthop 2009;38(3):E49-55. 